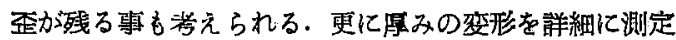
する必要がある。

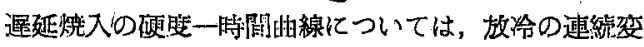
態を知る必要があるが，炭秦䤱については恒温变態圂の みによつても，或る程庭理解する哥が出来た：更にこの

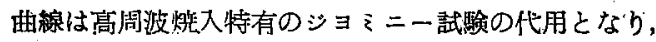
簡笚に变態速度を知る手段となる事を知つた。

なお炭萦堸の如き变態速度の早い材料を高周波烧入す る際,現埸では、水の遅れを非常に気䎲する人が多いが， その心配が殆んどない事がわかつた。

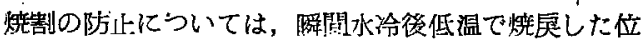
の硬度を目桠にすべきである。

以上述べた如く，契用を目的として研究を進めて来た のであるが，末だ原理を追求した程度に過ぎず，複雑な

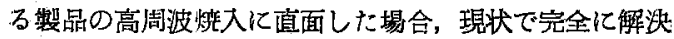
するものとは思つていない，場合によつては，中断烧入

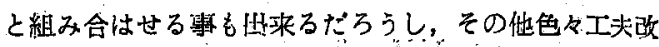
善されるべき点も多々ある事と思う：我々は生産の性颗

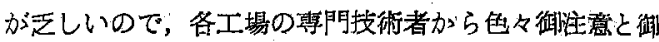
批判を仰ぎたいのである、排い研究ながら，我々の研然 が生库の一助ともなれば声甚である。

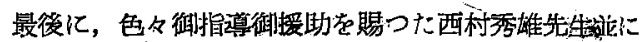

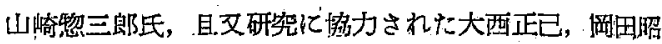

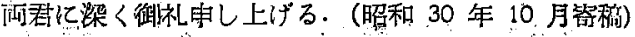

$$
\text { 艾 葻 }
$$

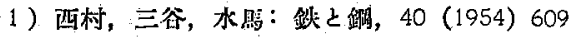

2）高瀨，三谷：日本金属学会誌，16(1952) 117

3) G. H. Brown: Radio Frequency Heating 189

4) J. F. Libsch, W. Chuang, W. I. Murphy:

Trans. A. S: M. $42-(1950) 121$

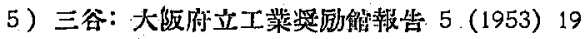

6) 大和久: S 此線 135

\title{
$\mathrm{Mn}-\mathrm{Cr}$ 肌焼鋼の低温焼戻脆性に及ばす $\mathrm{Al}, \mathrm{Ti}$ 及び $\mathrm{B}$ の影響
}

$$
\text { 扴川武*小川 清 “行* }
$$

\section{EFFECT OF Al, Ti AND B ADDITION ON THE LOW-TEMPERATURE TEMPERING EMBRITTLEMENT OF Cr-Mn CASE-HARDENING STEEL}

\author{
Takeshi Akutagawa, Dr. Eng. and Kiyoyuki Ogawa
}

\section{Synopsis:}

The cause of the hard tempered martensite brittleness which has come to be known as " $500^{\circ} \mathrm{F}$ embrittlement" has not been explained until today. The phenomenon was much related to the deoxidation, nitrogen-fixation, and austenite grain size of steel. The tempering characteristics of the steel plays a major role in the development of embrittlement. This investigation consists of a study of the effect of $\mathrm{Al}$, $\mathrm{Ti}$ and $\mathrm{B}$ addition on the impact resistance and an electron microscopic study of the manganese-chromium case hardening steel when tempered between $120^{\circ}$ and $420^{\circ} \mathrm{C}$. The results obtained are as follows:

(1) The Al- Ti $(0 \cdot 05 \sim 0.10 \%)$ addition markedly improves the impact values during tempering at these temperatures, especially with $\mathrm{Ti}$ addition the benefical effect in the temperature range of embrittlement is distinct.

(2) The tempering embrittlement temperature is not changed with the Al or Al-Ti addition and it occures at $300^{\circ}$ to $360^{\circ} \mathrm{C}$; however in the case of Al-Ti-B addition it is the temperature range at $300^{\circ}$ to $420^{\circ} \mathrm{C}$

(3) The impact minimum occurs in 20 to 30 minutes at the tempering embrittlement temperatures and the value is decreased with keeping time at $300^{\circ} \mathrm{C}$, it is almost constant up to $10 \mathrm{~h}$ at $360^{\circ} \mathrm{C}$.

(4) The transition temperature is lowered by the $\mathrm{Al}, \mathrm{Ti}$ and $\mathrm{Al}-\mathrm{Ti}-\mathrm{B}$ addition; with the Al $\left(0{ }^{\circ} 04 \%\right)$, Ti $(0.10 \%)$ and Al-Ti $(0.06 \%)-\mathrm{B}$ addition it falls down to $0^{\circ} \mathrm{C} \sim-10^{\circ} \mathrm{C}$.

(5) It is observed that the embrittlement arises from a precipitation of elongated thin

$\dagger$ 昭和 30 年 4 月本会陆演大会にて㧘演 * 東京大学工学部教授, 工博, 同大学院特研生 
cementite network along ferrite grain boundaries, with the B addition the formation is observed at the higher tempering temperature.

\section{I. 緒言}

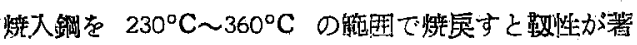
乙く減少する．との䍿の現像は低温烧㞔脆性又は $500^{\circ} \mathrm{F}$ 脆性として知られている. 通常武験条件は栃化を明確に

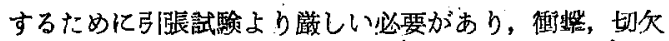

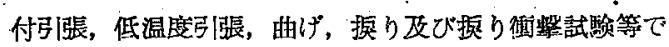
最低值が認められる、此等の試験では低温度, 歪速度の

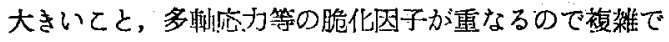

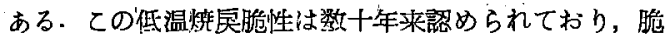
性に䦎しては多くの研究者の発表がある. 即ち Grossman'12残盛オースデナトが分解し分散した脆い微細 なa鉄が生ずるとしまた Luerssen 及び Green²は

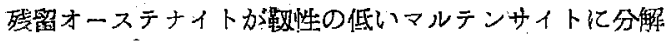
するためであるとの説, Castleman, Averbach 芯心゙ Cohen $^{3)}$ は残留オーステナイトは脆化の原因ではなくマ

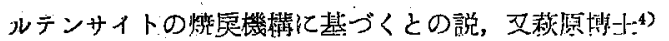
は、P,S の重影整殊にモリブデン,タンダステン,アルミ。 ニウムは燐の作用を打消すが，マンガンが多ければ低燐 のものでもかなり脆性が認められるという案験結果を示 している. 最近 Schradér, Wiester 及び Siepmann ${ }^{53}$

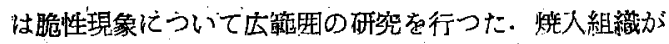
マルテンサイトであることが低温暁房脆性には必要条件

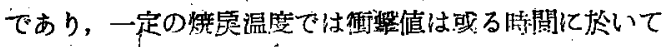
最低值を示し，爾後烍悬㭙間と共に回復している.との

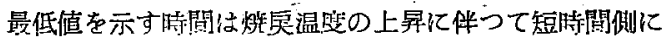

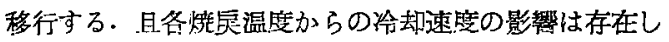

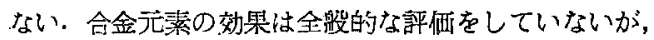

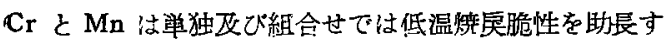
ると思われ，一方 $\mathrm{Mo}, \mathrm{W}$ 及び V は殆んど效果がない とと京し，1*7\% 及び $5 \% \mathrm{Ni}$ 鋼は脆性を示さなかつ た. また0・04\%以上の A.1 を添加すると脆化の度合は大
いに減じ， $0 * 10 \% \mathrm{Al}$ 添加で胞性加除かれるととを示し

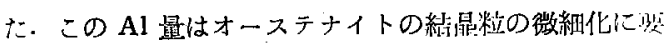
する最より多く，乙の笑踰から $\mathrm{Cr}$ 或は $\mathrm{Mn}$ 案化物の 析出が脆性の原因であると結詥し，A1 はオーステナイ。

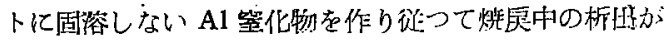

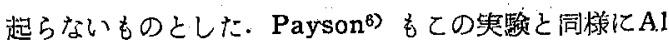
添加及びこれに Ti を源加した場台に脆性の減少するこ とを諗めているが，A.1 或は Ti の空化物当他の析江案

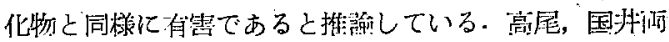

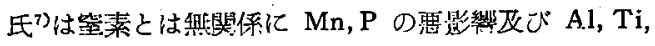

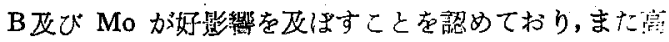

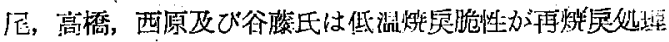
によつて認め難いため烧入組繖の分勒に伴う現象である と考光，河州，益子互び西田氏日は $\mathrm{Al}+\mathrm{Ti}$ 及び $\mathrm{Al}+$

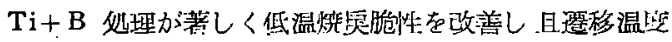
が低下するととを礁めている. Klinger，Troiano等10

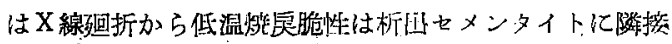
する薄いフェライト細であると云い, Lement; Aver-

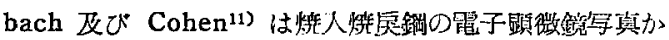
らオーステナイトの粒界にあるマルテンサイト板に沿う セメンタイトフィルムの生戌が脆性の原团になるととを 推諭した。

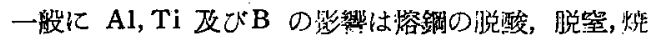
入性ないしオーステナイト維晶粒度等と检めて密接な囬 係があり，工業的にも重要であるので吾国でもこれら涯

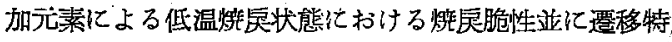
性に対する凑験坏告がなされている912)13)。

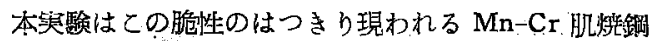

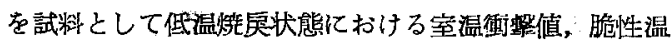

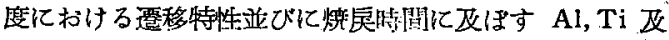

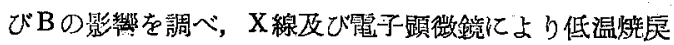

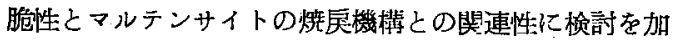

Table 1. Chemical composition, quenching temp.and grain size of steels tested.

\begin{tabular}{|c|c|c|c|c|c|c|c|c|c|c|c|c|c|c|}
\hline \multirow{3}{*}{ Mark } & \multicolumn{11}{|c|}{ Chemical composition (\%) } & \multirow{3}{*}{$\begin{array}{c}\text { Quench } \\
\text { temp. } \\
\left({ }^{\circ} \mathrm{C}\right)\end{array}$} & uster & G.S.No \\
\hline & \multirow[b]{2}{*}{$\mathrm{C}$} & \multirow[b]{2}{*}{ Si } & \multirow[b]{2}{*}{$\mathrm{Mn}$} & \multirow[b]{2}{*}{$\mathbf{p}$} & \multirow[b]{2}{*}{$\mathbf{s}$} & \multirow[b]{2}{*}{$\mathrm{Cr}$} & \multirow[b]{2}{*}{$\mathrm{Ni}$} & \multirow[b]{2}{*}{$\mathrm{Cu}$} & A1 & $\mathrm{Ti}$ & \multirow[b]{2}{*}{ d) } & & \multirow[b]{2}{*}{$\bar{N}$} & \multirow[b]{2}{*}{$\begin{array}{c}\text { Deviation } \\
(0)\end{array}$} \\
\hline & & & & & & & & & \multicolumn{2}{|c|}{$\begin{array}{l}\text { in mold } \\
\text { (computed) }\end{array}$} & & & & \\
\hline $\begin{array}{l}1 \\
2 \\
3 \\
4 \\
5 \\
6\end{array}$ & $\begin{array}{c}0.19 \\
" 1 \\
" 1 \\
" 1 \\
" 1\end{array}$ & $\begin{array}{c}0.33 \\
\text { "1 } \\
\text { "1 } \\
\text { " } \\
\text { " }\end{array}$ & $\begin{array}{c}0.80 \\
" 1 \\
" 1 \\
" \prime \\
"\end{array}$ & $\begin{array}{c}0.022 \\
" 1 \\
" 1 \\
" 1 \\
" 1\end{array}$ & $\begin{array}{c}0.012 \\
\text { "1 } \\
" 1 \\
" 1 \\
" 1 \\
\text { " }\end{array}$ & $\begin{array}{c}1.16 \\
" 16 \\
" 1 \\
" 1 \\
" 1\end{array}$ & $\begin{array}{c}0.14 \\
" 1 \\
" 1 \\
" 1 \\
" 1 \\
" \therefore\end{array}$ & $\begin{array}{c}0 \cdot 23 \\
\text { "1 } \\
\text { "1 } \\
\text { " } \\
\text { " }\end{array}$ & $\begin{array}{l}0.04 \\
\overline{0} \\
0.01 \\
0.02 \\
0.05\end{array}$ & $\begin{array}{l}- \\
- \\
0.02 \\
0.05 \\
0.10 \\
0.06\end{array}$ & $\begin{array}{c}\overline{-} \\
\overline{-} \\
\overline{-} \\
0.002\end{array}$ & $\begin{array}{l}900 \\
900 \\
900 \\
900 \\
1 " \\
" 1\end{array}$ & $\begin{array}{l}7 \cdot 5 \\
9 \cdot 6 \\
9 \cdot 3 \\
9 \cdot 1 \\
9 \cdot 9 \\
8 \cdot 8\end{array}$ & $\begin{array}{l}1 \cdot 7 \\
1 \cdot 2 \\
1 \cdot 3 \\
1 \cdot 2 \\
1 \cdot 1 \\
1 \cdot 1\end{array}$ \\
\hline
\end{tabular}


えたものである。

\section{II. 供 圾 材}

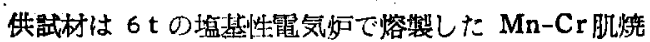
取鍋上り鋳型に注入の際鋳型に揢湯が $1 / 3$ 程度充さ れたとき1. 源加㓩なし，2. アルミニウム $(0.04 \%)$ ， ミ. フェロチタン (Ti として 0.02\%), 4. フェロチタ ン ( $\mathrm{Ti}$ として 0*05\%), 5. フエロチタン ( $\mathrm{Ti}$ として $0.10 \%)$ 飞び 6. アルミニウム $(0.05 \%)$ とフエロチ夕 シボロン (Ti として 0.06\%, Bとして0.002\%) をて れぞれ添加しだ. 但しフェロチタン中には Al を Ti の 約 $1 / 5$ 量含有するため $3 ， 4$, 及び 5 の武料には微量の Al を同時源加したととになつている. この栚な $160 \mathrm{~kg}$

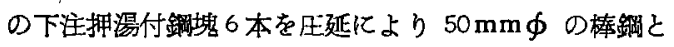
したものを供試材としだ：ての添加方法沉就いては予め

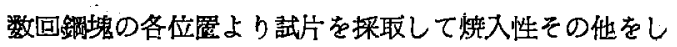
らべ，充分均一に拉散分布しているととを確めた，銅塊 加熱は $3 \mathrm{~h}$, 㞋出温度は $1160^{\circ} \sim 1190^{\circ} \mathrm{C}$, 仕上温度は 1040 1060 C であつた. Table 1 亿は供武材の組成 (Al，Ti 文びBは何れも添加量を示す），㛙入温度及び オーステナイト結晶粒度 $\left(925^{\circ} \mathrm{C} \times 1 \mathrm{~h}\right.$, 酸化法による)

とその標潐偏差を次の計算式

$$
\begin{aligned}
& \text { 平均粒度 } \bar{N}=\frac{11}{100} \sum_{i} N_{i} \mu_{i} \quad \mu_{i}: \text { 体積分率 } \\
& \text { 榡準偏差 } \quad \sigma=\Sigma \sqrt{\frac{1}{100} \sum_{i} \mu_{i}\left(N_{i}-\bar{N}\right)^{2}}
\end{aligned}
$$

に基づいて得た值を示す.

涯加便用したフェロチタンは Ti $46 \cdot 1 \%$, Al $10 \cdot 8$ $\%$, Si $1 \cdot 2 \%$, C $0.07 \%$ 及び P $0.10 \%$ の ロチタンボロンは Ti $24 \cdot 22 \%, \mathrm{~B} 3 \cdot 02 \%, \mathrm{Al} 7 \cdot 08 \%$, 夜び C $0.023 \%$ のもので何れも 5 10 mm 程度の粒 状にした。

\section{III. 実 験 方 法}

前記の素材を $950^{\circ} \mathrm{C}$ より焼淮後機械加エしてシャル ピー武験片とし，眖炭を防止しつつ下記の熱処理を行つ た上，正規の寸法に仕上げた．また上記の素材より標準

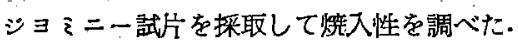

(i) 㬴入: $900^{\circ} \mathrm{C} \times 30 \mathrm{mn}$ 油冷

(ii) 㜔戻: 焼入のまま, $120^{\circ}, 180^{\circ}, 240^{\circ}, 300,360^{\circ}$ 及 び $420^{\circ} \mathrm{C}$ にそれぞれ $2 \mathrm{~h}$ ，焼戻後空冷した試片につき 焼戻温度の影響を求めた。

(iii) 㜔戻時間: 焼㞔温度 $300^{\circ} \mathrm{C}$ 及び $360^{\circ} \mathrm{C}$ 亿それ。 ぞれ $5 \mathrm{mn}, 10 \mathrm{mn}, 20 \mathrm{mn}, 30 \mathrm{mn}, \cdot 1 \mathrm{~h}, 2 \mathrm{~h}, 5 \mathrm{~h}, 10 \mathrm{~h}$ 及 び 16h したものにつき㜔联時間の影響を調べた。

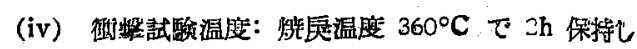
たものな $-70,-40,-20,0,25,50,100,150$ 及ひ $200^{\circ} \mathrm{C}$ の各試酸㴜度に $30 \mathrm{mn}$ 保持して武験し遙移特生 を求めた. $0^{\circ} \mathrm{C}$ 头下の温度に保つた寒剂より取环して酸 断するまでの時間は 3秒斗内とし, その閔の温度变化は 無視した。寒剂はェチルアルコールとにライアイスの混 合物を使用し，同一条件の下で行つた 2〜3ケ測定值の 平均値をとつだ。

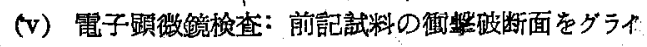
ンダーで荒削りしペーパー並にバフ研磨せるものを $4 \%$

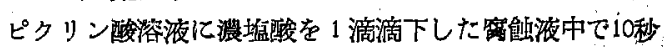

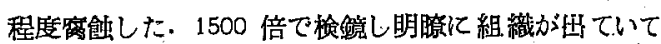
，且つ窝凔液残查のないものを選びその表面にコロヂオン 0.5\% の酰酸アミル溶液の潮膜を作り，7 c.p.s. の7\% トリクロールエチレン溶液で補強し，てのネガテイブレ プリカを $50 \sim 55^{\circ} \mathrm{C}$ の湯中で剥離し， $1^{-6} \mathrm{mmHg}$ の真 空中でクロムシャドウイングをフイラメントの電流を調 節して $1 \mathrm{mn}$ 間で行つた。角度はコントラストを考虑し て $30^{\circ}$ とした，次に補強のエト七儿溶解と洗沙をか极 てトリクロールエチレン溶液中で 2 回洗源し雷子顕微鏡 レフリリカとた，撮影は直接 4000 倍で撮り之を 14000 倍に引伸した。

X線廻折に用いた炭化物の電解分離法は 10:1 の壏酸

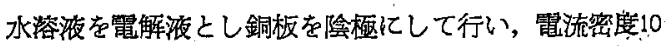
$\mathrm{mA} / \mathrm{cm}^{2}$ で電解時間 $60 \mathrm{~h}$ の途中電解液の半分を新解 な液と置換へ，鉄が㓌極に析出するのを防いだ. 侗分離 炭化物は酸から僈されるのを最少にするためグリセリン 中に集めた. 残洫は水とアルコールでグリセリンを洗い 落し、アルコールはアミルアセテートで繰返し洗涤し除 いた。

デバイ写真は分㒕した炭化物行いて，Coターゲ， トを使用して撮影した。

また分離炭化物の電子顕徽鏡写真をとるため宸化物を

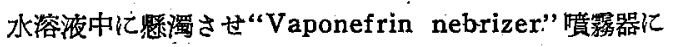
より $0.1 〜 5 \mu$ の荡滴をコロシオン膜上に吹きつけた。

\section{IV. 実験結果並に考察}

(1) 焙入性

標準ショミニ一武片による烍入硬度曲線を求めた結果

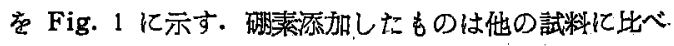
て鈤入性の向上が顕著であることがわかる。

（2）酸化法により求めたオーステナイト結晶粹度は Table 1 亿示す様に添加処理 行わないるのが最も粗. く、アルミニウム及びチタニウムによる粒度の微粒化作 


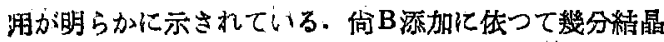

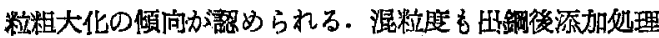

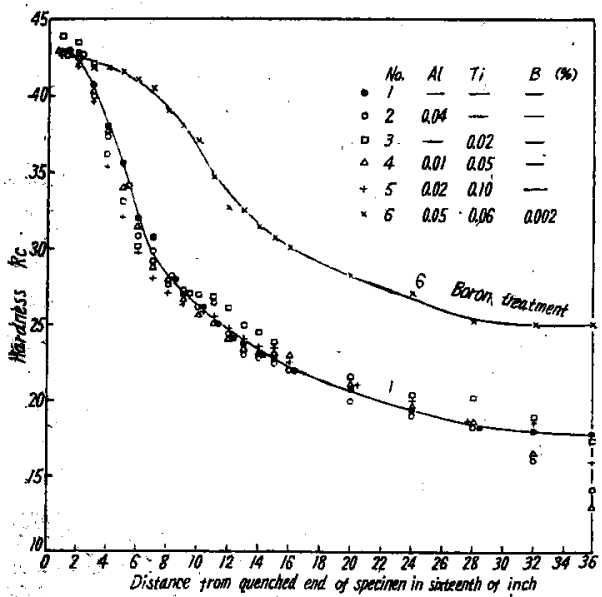

Fig. 1. Hardenability curves of steels tested

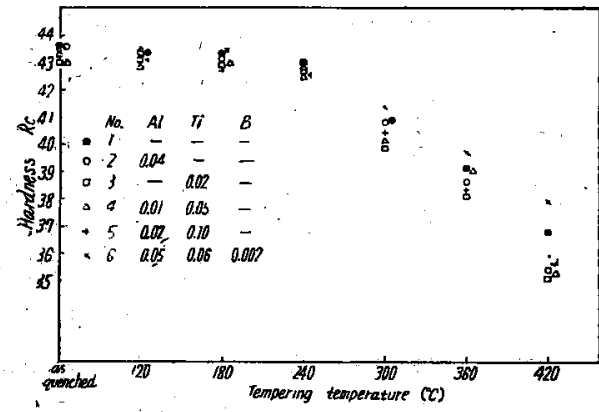

Fig. $:$ Tempering temperature-hardness curves of steels tested.

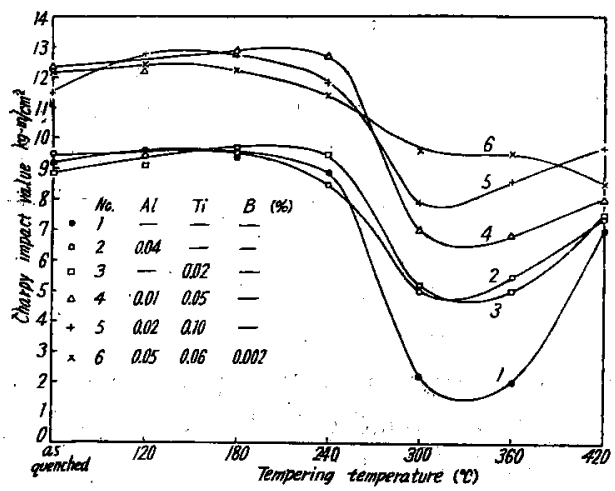

Ftg. 3. Charpy impact values for quenched steels as a function of tempering temperature.

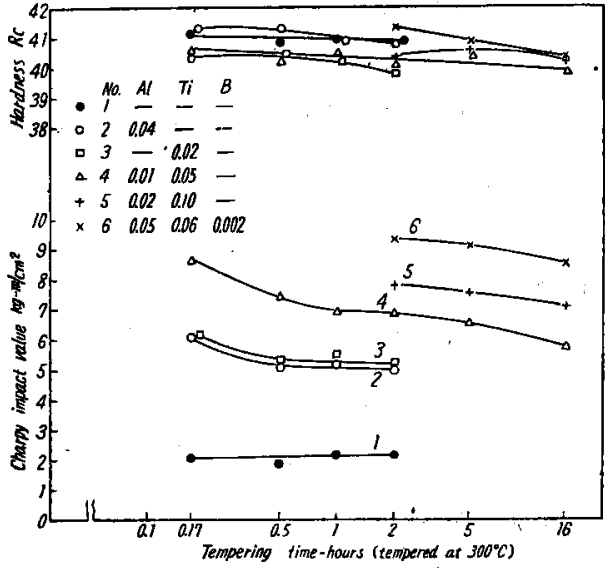

Fig. 4. Charpy impact value and hardness for steels tested as a function of tempering time.

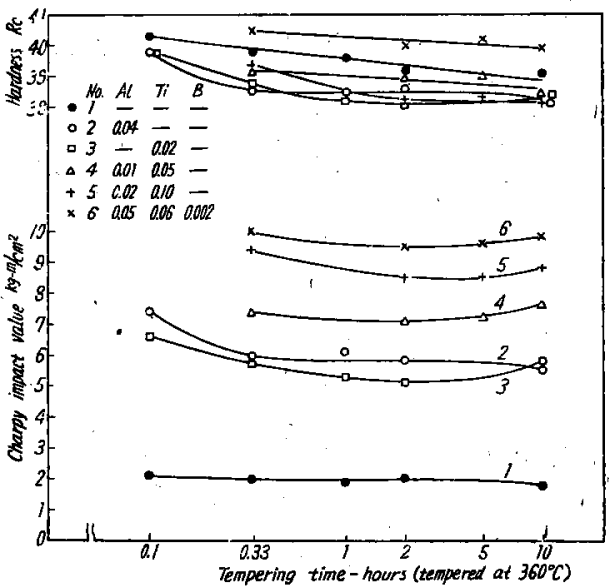

Fig. 5. Charpy impact value and hardness for steels tested as a function of tempering time.

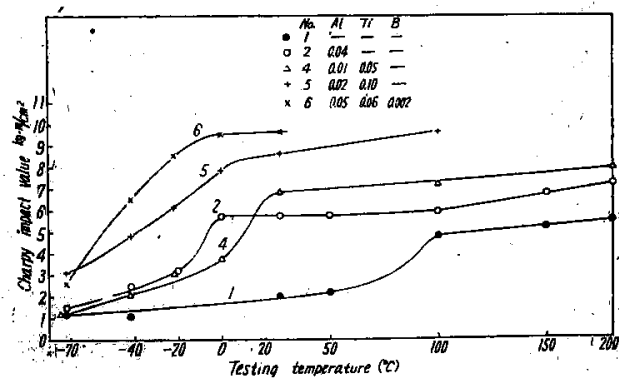

Fig. 6. Transition curves for steels tested as tempered at $360^{\circ} \mathrm{C}$ for 2 hours. 


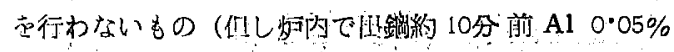
加えている) 加巤大大である。

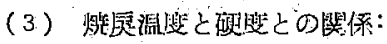

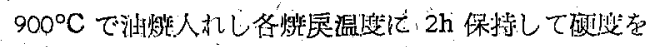

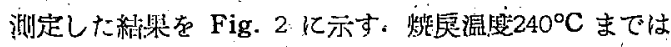

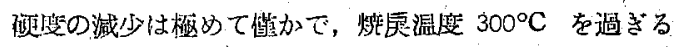

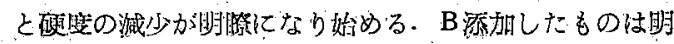

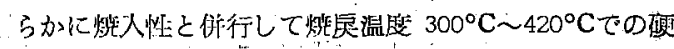

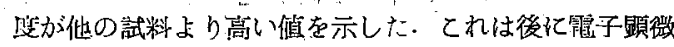

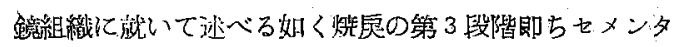
イトとフエライトになる烧原過程がBにより掘れるため ごあうっ。

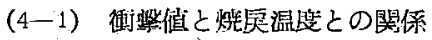

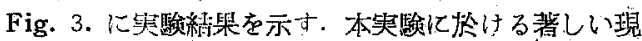

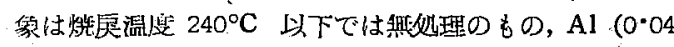

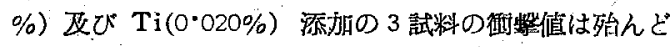
滆一で 8.5 9.5 $\mathrm{kg}-\mathrm{m} / \mathrm{cm}^{2}$ であるが $\mathrm{Ti}(0.05 \%), \mathrm{Ti}$ $(0.10)$ 及心゙ Al $(0.05 \%)+$ Ti $(0.06 \%)+$ B $(0.002 \%)$ 源加を行つた 3 試料は前記の武料より2〜 $3.5 \mathrm{~kg}-\mathrm{m} / \mathrm{cm}^{2}$

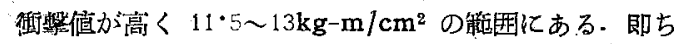
$\mathrm{Ti} 0.05 \%$ 以上添加した場合唒啮徝の间上が著しい。無 处理のもの, $\mathrm{Al}\left(0^{\circ} 04 \%\right)$ 㬄加したるの及び $\mathrm{Ti}\left(0^{\circ} 02 \%\right)$ 添

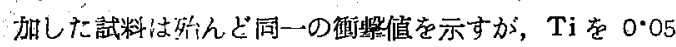

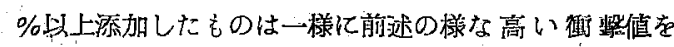
示し，またB処理した武料は $\mathrm{A} 1$ 或は Ti添加した試料よ

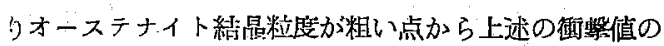

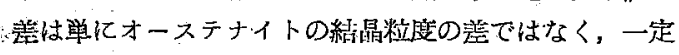

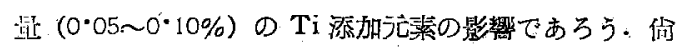
銅酳酸溶液による析抵空化物最に対する渿加元素による

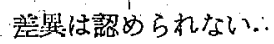

Payson ${ }^{6)}$ が Al 0.015〜0:25\%の箱国で变光脱等

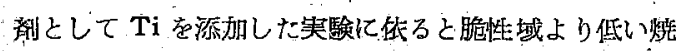
㞔温度の衡慗值が低下するてとを示しており，Schra-

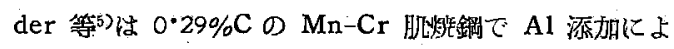

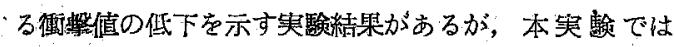
Ti $\left(0^{\circ} 05 \%\right)$ 添加に依り衝慗值は改善されている.

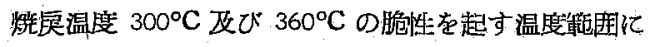

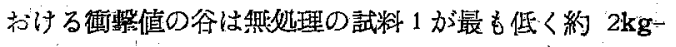
$\mathrm{m} / \mathrm{cm}^{2}$ で, Al $\left(0^{\circ} 004 \%\right)$ 或は Ti $\left(0^{\circ} 02 \%\right)$ 添加した ものはをれぞれ $5 \mathrm{~kg}-\mathrm{m} / \mathrm{cm}^{2}, \mathrm{Ti}(0 \cdot 05 \%)$ 渿加で 7 $\mathrm{kg}-\mathrm{m} / \mathrm{cm}^{2}, \mathrm{Ti}(0 \cdot 10 \%)$ 添加で $8 \mathrm{~kg}-\mathrm{m} / \mathrm{cm}^{2}$ 及ひ Al $(0.05 \%)+\operatorname{Ti}(0.06 \%)+\mathrm{B}(0.002 \%)$ 源加て $9.5 \mathrm{~kg}-$ $\mathrm{m} / \mathrm{cm}^{2}$ となり脆性は著しく改善されている. 各々の試

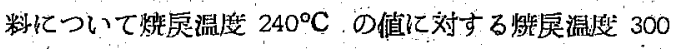

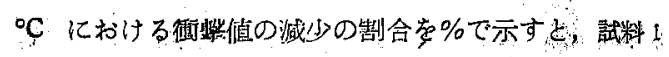

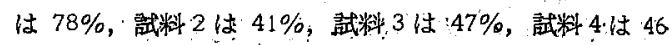

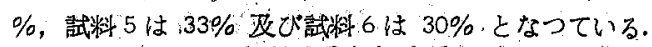

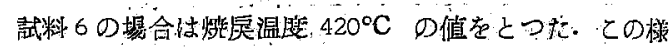

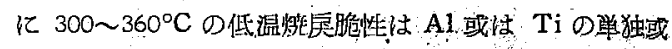
は組合せ涯加により，珠に Ti 源加てようて著しく政善

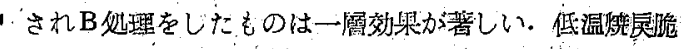

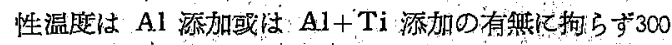
〜360 $\mathrm{C}$ の間であるが, B 处理をしたものは焙虞温度

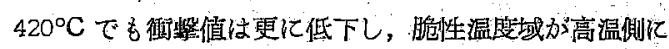

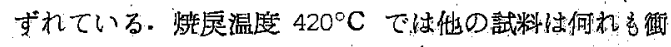
紫值は回復し 7〜 $10 \mathrm{~kg}-\mathrm{m} / \mathrm{cm}^{2}$ を示している.

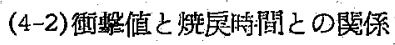

睈性を起す焼㞓温度 $300^{\circ} \mathrm{C}$ 及び $360^{\circ} \mathrm{C}$ 亿於ける保持

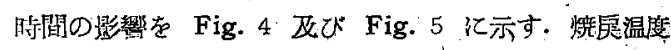
$300^{\circ} \mathrm{C}$ では 10mn で無処理のものは衙慗值の最低を示 L, Al $(0.04 \%)$, Ti $(0.02 \%)$, 攻び Ti $(0.05 \%)$ 添 加の試料估监 $1 \sim 1.5 \mathrm{~kg}-\mathrm{m} / \mathrm{cm}^{2}$ 高い值を示している が, 30mn で殆んど脆化し，境扈特間 $16 \mathrm{~h}$ では約 $1 \mathrm{~kg}$ $\mathrm{m} / \mathrm{cm}^{2}$ の低下を示し脆性の谷が $300 \sim 360^{\circ} \mathrm{C}$ の聞市 るととが推定される.燈㞔温度 $360^{\circ} \mathrm{C}$ で住保持特間 5

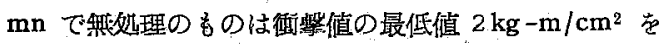
示し,Al (0.04\%) 添加のもの及び Ti (0.02\%) 添加 の武料では約 $1.5 \mathrm{~kg} \mathrm{-m} / \mathrm{cm}^{2}$ 高い值を示すが $20 \mathrm{mn}$ 纪 なると脆化し，保持時䦥 $10 \mathrm{~h}$ までの垁験では衙紫值の 变化は殆んどない. Ti(0.02\%), Ti $(0.05 \%)$, Ti $(0.10$ $\%)$ 飞び A1 $(0 \cdot 05 \%)+\mathrm{Ti}(0 \cdot 06 \%)+\mathrm{B}\left(0^{*} 002 \%\right)$ 添加

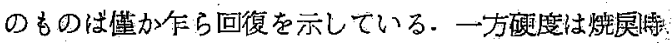

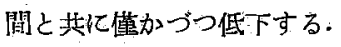

\section{(4-3) 筑掏值之試融温度の関係}

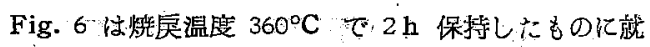
いての僄移特性曲線を示す，僄移温度 ( Tr)には種々の 定䇅があるが，とてでは Frácture transion に相当す ろ䩲性の低下し始める温度とする。

$\operatorname{Tr}$ 被䁈处理の場合は約 $100^{\circ} \mathrm{C}$, Ti $(0.05 \%)$ 添加 したものが $25^{\circ} \mathrm{C}$ K下り, Al $(0 \cdot 04 \%), \operatorname{Ti}(0 \cdot 10 \%)$ 及び Al $(0.05 \%)+\mathrm{Ti}(0.06 \%)+\mathrm{B}(0.002 \%)$ 添加し たものは何れる $0^{\circ} \sim-10^{\circ} \mathrm{C}$ 低下している。 Al 低び

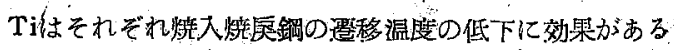
がB源加がをれ上上の效果を有するとは云えない，

(5) 破断面の状沅

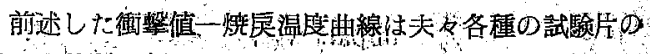
破断の状洒刘店している.

一般に脆性域以外では刑断型䂭面を呈するに反して, 


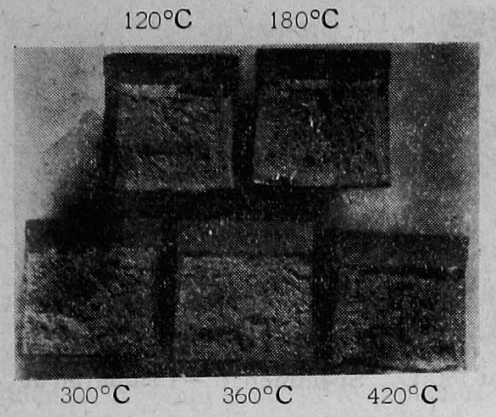

Photo. 1. Fractured surface of No. 1 alloy quenched and tempered 2 hours at temperature in the range of $120^{\circ}$ to $420^{\circ} \mathrm{C}$.

$300 \sim 360^{\circ} \mathrm{C}$ の脆性域ではかなり䢃開型破面を示してい る. その代表面な例を Photo. 1 に示す. 試料は無処理 のちので，焼戻温度 $120^{\circ} \mathrm{C}, 180^{\circ} \mathrm{C}$ 及び $240^{\circ} \mathrm{C} て ゙ は$, ツチ底部及び両側面に塑性变形部を残留しているが 300 。C 及び $360^{\circ} \mathrm{C}$ では殆んど㖕開型を示している.その 优の添加試料では脆性の谷の深さに刘応して,ッチ立び に两側面の塑性変形の割合が試料 1 に䡆べて多くなり， 何れも焼戻温度 $420^{\circ} \mathrm{C}$ では剪断型破面を呈して来る. しかし B潦加の武料では塑性变形部の制合は烍厌温度と 共に減少している．脆化領域の破面は光㳄のある刻面を 持つていろのが特長である.

\section{（6）分離㞸化特のX線迴折}

試料 1 の電解分離残椬に就いてX線迴折（デバイ・シ エラー法）を行つたところマルテンサイト分解生成物に 刘する焼㞎温度の効果が或る程度判明した，劣本実験試 数はC\%が低く従つて析亚している炭化物の大さか極め て小さいので粗大化させるため烧戻時間を適当に長くし た. 即ち以下の实験は焼戾佶閒 $50 \mathrm{~h}$ で行つた結果であ る. 焼帍温度 $240^{\circ} \mathrm{C}$ の試料では痕䟢の 8 宸化物とセメ ンタイトの線がみられる・\&炭化物の (101) 線は極めて 强度が強いことが特脣でとれがセメンタイトの中間強度 の (121) 線と (210) 線の間にはさまれ太く強く現われ ている、を炭化物はセメンタイトの (112) 線と重なる (100) 線と (110) 線灰び (103) 線の弱い線がみられ ろ. 䶊戻温度 $300^{\circ} \mathrm{C}$ の試料では 8 炭化物は消えセメン タイトの線のみであり, 焼戻温度 $420^{\circ} \mathrm{C}$ の試料ではセ メンタイトの (140)，(233）及び (330) 線が中閒強度 で㸵ている.

（7）電子影微鏡に依る観察

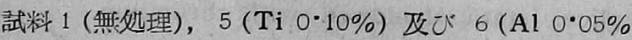
- Ti $0.06 \%$ + B 0.002\%) の 3 試料を対参として, 烧 巨過程の組織变化を電子顕微 鏡に佧つて調べた結果を

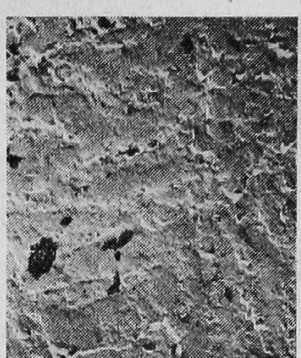

Photo. 2. Electron micrograph at $\times 30,000$ of No. 1 alloy quenched and tempered 2 hours at temperature $180^{\circ} \mathrm{C}$.

Photo. 2 及ぴ 3 に示す.

焼戻温度 $120^{\circ} \mathrm{C}$ : 武料 1 では粒界に平行或は一定の倩 度に規則正しいう向性を示している板状マルテンサイト が謥められ，板状マルテンサイトに沿い白い薄膜状の遷 移宸化物が認められる. 陚料 5 及び6ではオーステナイ 卜粒内の方位差は明瞭であり, 試料 1 亿比し, 板状マル テンサイトの方向性は少く，且マルテンサイト板内に粒 状㞸化物の析出かかなりみられる. 試料 6では析出物は 粒内で或る一定の閒隔を以てマルテンサイト板内に存在 している。

焼戻温度 $180^{\circ} \mathrm{C}$ ：陚料 1 ではかなり微細な析出物が 不均一に板状マルテンサイト或は西粒界に沿つて析出し ているのがみられる．尙窗咀時間を $2 \mathrm{mn}$ にして 30,000 倍で撮つた Photo. 2 では明らかに亜粒界に沿い膜状遷 移宸化物が網状に不連続に析出している．覀粒界の大さ は $10^{-4} \mathrm{~cm}$ の程度である. 上記の析㞷物は特にオース テナイト粒界に沿つて析世する傾问を認めない. 試料 5 改ひではマルテンサイト板内に粒状宸化物が多数あり マルテンサイト板に沿うものは薄膜状になつている.

烓㞍温度 $240^{\circ} \mathrm{C}$ ：試料 1 のオーステナイト粒内の方 向性は減少し，比輍的大さい膜状宸化物がマルテンサイ ト板に沿い，又粒内では亜粒界に沿つて糸状宸化物がか なりはつきり不連続に存在している。試料 5 及び6では 武料 1 程明瞭な析开はみられないが, マルテンサイト板 或はマルテンサイト板内の业粒界に沿い微小炭化物の析 出が不均一にみられる。

烍居温度 $300^{\circ} \mathrm{C}$ ：試料 1 はオーステナイト粒内の方 向性をもつたセメンタイトの析蛊が殆んど完了してい る. セメンタイトは棈円或は細長い棒状に $0 \cdot 2 \sim 1 \mu の$ 範囲でマルテンサイト板に沿つて不連続に網状を呈して 析出し，マルテンサイト内では覀粒界に沿い粒状叉は球 状の微細な析出がみられる.武料 5 及び 6 もメンタイ トの析正は明膫であるが，試料 5 ではマルテンサイト板 


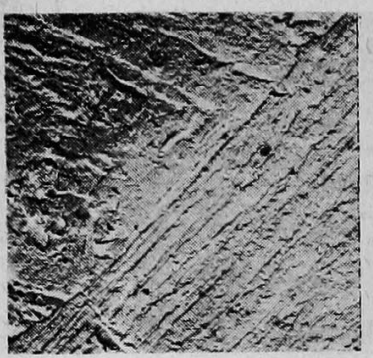

Specimen 1 - Tempered at $120^{\circ} \mathrm{C}$

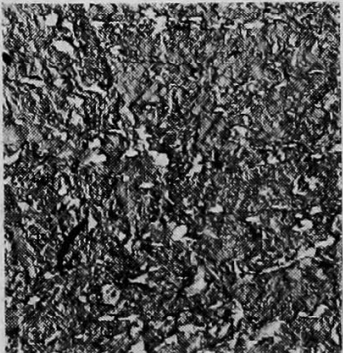

Specimen 1 - Tempered at $300^{\circ} \mathrm{C}$

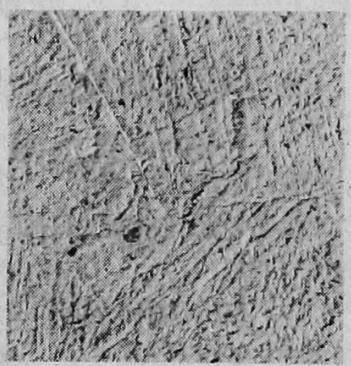

Specimen $5-\mathrm{Tempered}$ at $120^{\circ} \mathrm{C}$

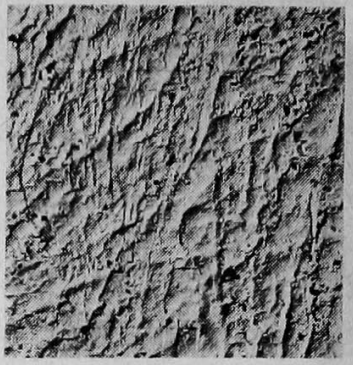

Specimen 1 -Tempered at $180^{\circ} \mathrm{C}$

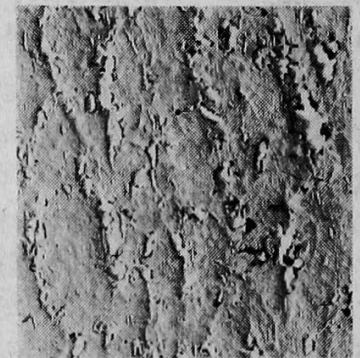

Specimen 1 - Tempered at $360^{\circ} \mathrm{C}$

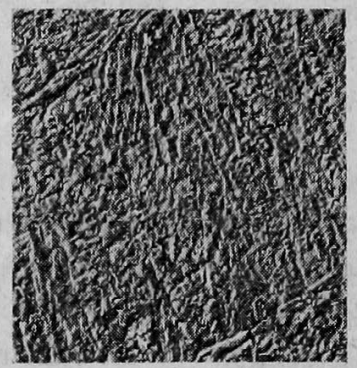

Specimen $5-$ Tempered at $180^{\circ} \mathrm{C}$

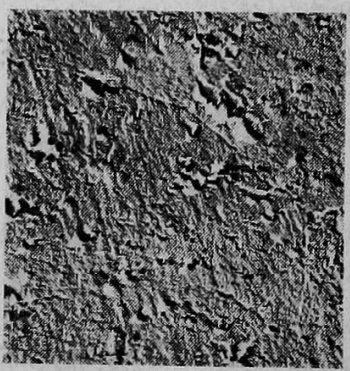

Specimen 5 - Tempered at $360^{\circ} \mathrm{C}$

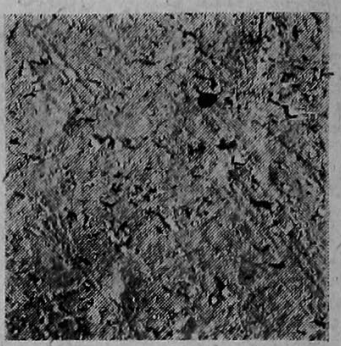

Specimen 1 - Tempered at $240^{\circ} \mathrm{C}$

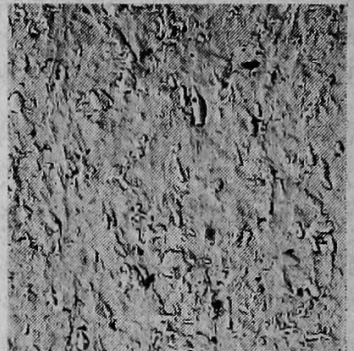

Specimen $1-$ Tempered at $420^{\circ} \mathrm{C}$

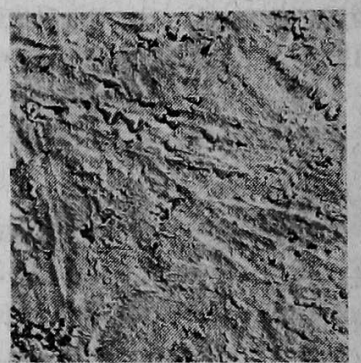

Specimen 5 -Tempered at $240^{\circ} \mathrm{C}$

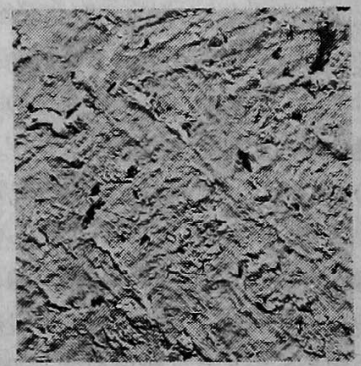

Specimen $5-\mathrm{Tempered}$ at $460^{\circ} \mathrm{C}$

Photo. 3. Electron micrographs at $\times 14,000$ of No. 1, No. 5 and No. 6 alloy quenched from $900^{\circ} \mathrm{C}$ and tempered 2 hours at temperatures in the ranges of $120^{\circ} \mathrm{C}$ to $420^{\circ} \mathrm{C}$. Ethecel reinforced collodion replicas static-shadowed with chromium. 


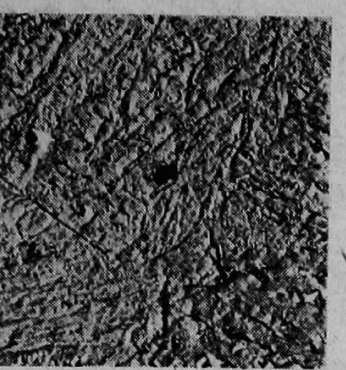

Spectmen 6-Tempered at $120^{\circ} \mathrm{C}$

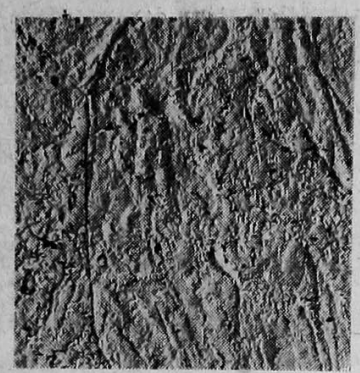

Specimen 6 - Tempered at $180^{\circ} \mathrm{C}$

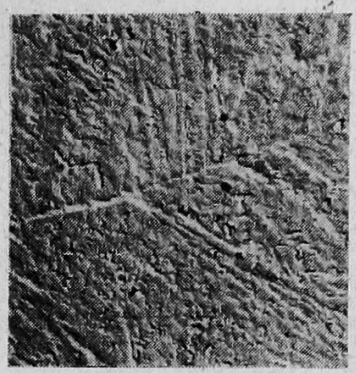

Specimen 6 - Tempered at $240^{\circ} \mathrm{C}$

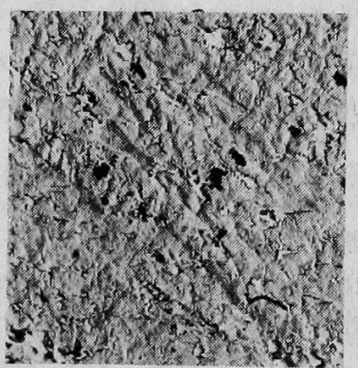

Specimen 6 - Tempered at $420^{\circ} \mathrm{C}$

Specimen 6 - Tempered at $300^{\circ} \mathrm{C}$

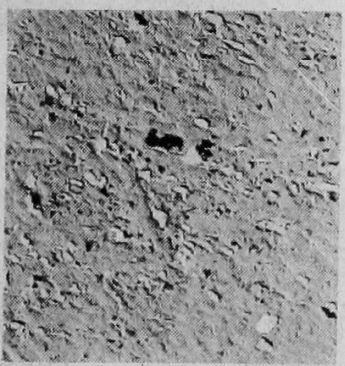

Specimen 6 - Tempered at $360^{\circ} \mathrm{C}$ Photo. 3-(Continue)

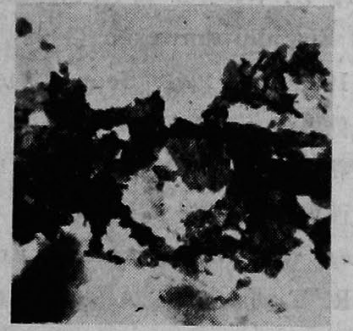

T.T. $240^{\circ} \mathrm{C}$

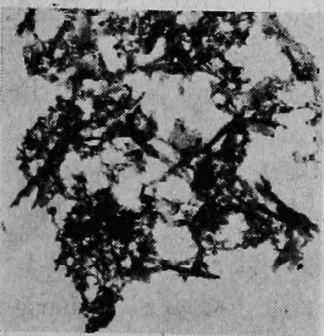

T.T. $360^{\circ} \mathrm{C}$

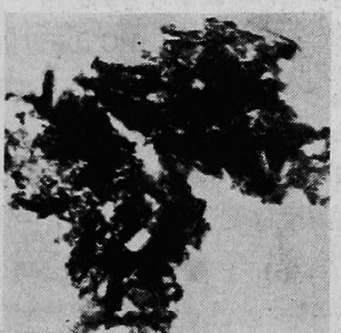

T.T. $420^{\circ} \mathrm{C}$

Photo. 4. Electron-micrographs of cementite in tempered troostite structure, tempered at $240^{\circ} \mathrm{C}$ to $420^{\circ} \mathrm{C}$ for 2 hours $\times 30,000(1 / 2)$

纪沿つて長さ約 $1 \mu$ の棒状或は $0.5 \mu$ の楕円状フィル ムとなつて析出し，武料6では一般にこれ等が丸昧を呈 している・またマルテンサイト板内では何れも粒状の微 小析出物が認められる.

焼㞔温度 $360^{\circ} \mathrm{C}$ ：武料 1，5 及び 6 共にマルテンサ イト板に沿うセメンタイトフイルムの粗大化がおこり， マルテンサイト板内の微小粒状宸化物は吸収され，セメ ンタイトフイルムはフェライトを囲み影状を呈して来 る. 恐らくこの牂状炭化物が脆性の原网であろう. 特に 武料 1 にとの現象が顕著である. 武料 6 は試料 1 及び 5 にこ畑べャメンタイトフィルムの粗大化の傾向が小であ 3.

焼厚温度 $420^{\circ} \mathrm{C}$ ：試料 1 及び 5 のマルテンサイト板
に沿うセメジタイトフイルムの粗大化は一層進行し，七 メンタイトは何れも球状を呈して来るが，試料6ではフ エライトを囲む不連続セメンタイトフイルムの㩆状組織 がやや明睹にみられる. B処理の武料がての温度で脆性 を示している点からフェライトを囲んでセメンタイトフ イルムが最状に伸びている場合にはそれが脆性を招き， セメンタイトフィルムが粗大化して球状化した場合には フエライトの僅性により衝撃值は向上する。

以上を総括すると焼厌温度 $240^{\circ} \mathrm{C}$ までが焼戻の第一 段階であり，焼入のマルテンサイトは低崖素の正方晶マ ルテンサイトであり，その亜粒界に沿い 8 宸化物の析出 がすられる.この析师は燅厌温度 $300^{\circ} \mathrm{C}$ では消失し， セメンタイトがマルテンサイト板に沿い０・2 1 1 程度 
のフイルムとして，またマルテンサイト内では球状乃至 小さな板状となつて䉼陮し，地はうェライトになる。烧 实の第三段階はセメンタイ卜の析址し始める $240^{\circ} \mathrm{C}$ わ らとみるべきであろう・脆性はセメンタイトの析性が完 了し, マルテンサイト板に沿うセメンタイトがマルテン サイト内の球状乃至板状微小セメンタイトを吸収し，フ エライトを䀧题状セメンタイトフイルムの形成により

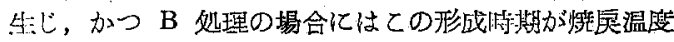
$420^{\circ} \mathrm{C}$ にずれている.

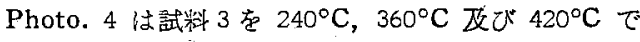

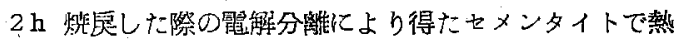
処理により微細な㺃膜の题状セメンタイトが漛状に粗大 化している傾向が，かなりはつきりみられる。

\section{V. 総 括}

代导験では $\mathrm{Mn}-\mathrm{Cr}$ 肌煤鋼に Al, Ti 及び B の添加

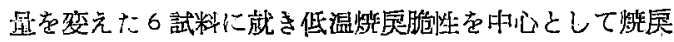

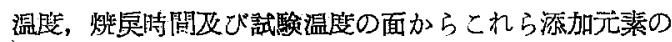

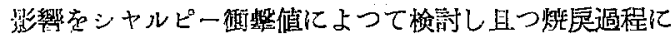
伴う組䍃の变化を電子顕微鏡で観祭して脆性の原因を㺃 べた・その結果を総括すると次の如くである。

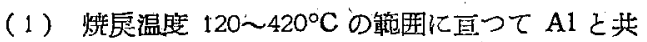
に Ti $0.05 \sim 0.10 \%$ の添加により征盟值は明ら加に政 栍せられる。

（2） Al 而び Ti の添加殊に後者により $300 \sim 260^{\circ} \mathrm{C}$ の低温㹸厚脆性は著しく歌善され，B処理は一層効果を

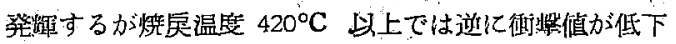
する傾间を示す。

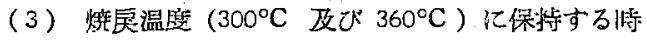

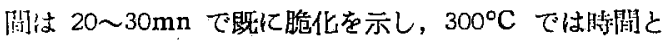

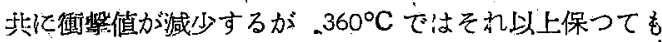

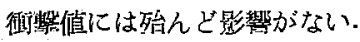

（4）遷移温度は無処理の試料加約 $100^{\circ} \mathrm{C}, \mathrm{Ti}\left(0^{\circ} 05\right.$

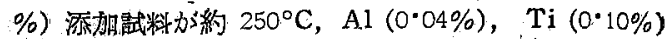
及びB处理のものは何れる $0^{\circ} \sim-10^{\circ} \mathrm{C}$ 亿焦下を示して いる.

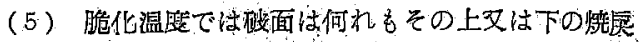

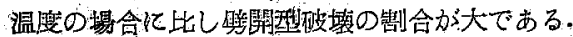

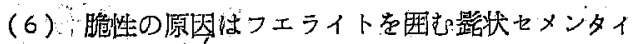
トにあるものと推定せられる。B源加によりその生成が 高温度側にずれる。

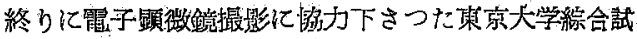

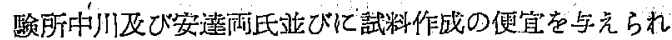
た株式会社東京製鎆所中臬意一氏その他に厚く感謝する (昭和 30 年 10 月答嗬) 文 调

1) Marcus A. Grossman: Iron Age (1924)114 II , 149

2) G. V. Luerssen \&. O. V. Greene: A.S.M. 23, (1935) 861

3) S. Castleman, B. L. Averbach \& Morris Cohen: A.S.M. 44, (1952) 240

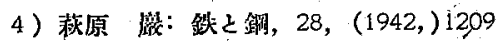

5) H. Schrader, H. Wiester \& H. Siepmann: Archiv fu d Eisenhüttenwesen (1950)21, 2I

6) P. Payson: Iron Age (1951,) Sept. 27, 168

7) 高尾，国井：铁と凃，38(1952) 110

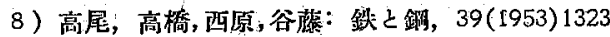

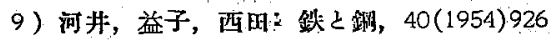

10) L. J. Klingler, W. J. Barnstt, R. P: Frohmberg \& A. R. Troiano: T.A.S.M. 46(1954)" 1557

11) B. S. Lement, B. L. Averabch \& Morris Cohen: T.A.S.M. 46(1954)851

12）河井，井上, 小川：鉄已铜，39(1953) 1.16

13）河井，西田：钱它钢，40(1954)38: 